\title{
スローアウェイ型 $\mathrm{CBN}$ ホイールによる \\ アモルファステープの研削に関する研究 \\ (第 1 報)*
}

一研削特性について——

王 序進 ${ }^{* *}$ 庄司克雄 ${ }^{* * *}$ 时川常元 ${ }^{* *}$ 田中憲司*** 茂木克己 ${ }^{*}$

Studies on Grinding of Amorphous Tape with Throw-Away CBN Wheel (1st Report)

- Grinding Characteristic-

Xu-Jin Wang, Katsuo Syoji, Tsunemoto Kuriyagawa,

Kenji Tanaka and Katsumi Mogi

\begin{abstract}
The grinding of amorphous tape is regarded as extremely difficult due to the loading of the wheel during the grinding process and due to the crystallization of the amorphous tape caused by grinding heat. By taking advantage of excellent grinding performance of endless CBN abrasive belts, a new grinding wheel system constructed of endless CBN abrasive belts (namely a throw-away $\mathrm{CBN}$ wheel) was developed. In order to improve the ground workpiece surface waviness and roughness, a Low-frequency Vibration Grinding Method (LFVGM) was creatively put forward. In this paper, both the theoretical analysis and experiment research of LFVGM on improving ground workpiece waviness were carried out. An experiment investigation on grinding performance with a throw-away CBN wheel in continuous-feed grinding of amorphous tape was also conducted. Experiments show that the ground amorphous tape roughness $R_{\max }$ value is below $0.8 \mu \mathrm{m}$ by using \# 600 endless CBN abrasive belts.
\end{abstract}

Key words : amorphous tape, grinding wheel, abrasive belts, throw-away CBN wheel, belt grinding, low-frequency vibration grinding method, continuous-feed grinding

\section{1. 緒 言}

アモルファステープは磁性材料の新素材として, 優 れた特性を持ち, 各種トランス, 磁気へッド，センサ などへの応用が期待されている ${ }^{122)}$. しかし, 通常, アモルファステープは単一ロール急冷法で作られるた め表面粗さが悪く, 実用化には表面仕上げが必要であ る.ところがアモルファステープは, 硬度が高い上に 高しん性のため砥石が目つぶれと目づまりを起こしや すく，しかも研削熱による表面の再結晶化が問題とな ク，研削加工は困難である．これは，アモルファス テープの用途の払大に対して，大きな障害となってい る.

* 原稿受付 平成 4 年 1 月 13 日

** 正会員 重慶大学工学部 (中国四川省重度市沙坪垻区 沙坪正街 174 号)

*** 正会員 東北大学工学部（仙台市青葉区荒巻字青葉）

$†$ 三菱マテリアル(株)商品開発センター- (大宮市北袋町 1-297)
$\mathrm{CBN}$ 研削ベルトは, 通常の CBN ホイールに比べ て, 目づまりを起こし難く, しかも研削熱の発生が少 ない. 本研究は, $\mathrm{CBN}$ 研削ベルトのこのような特性 に注目し，新しいベルト研削方式として，アイドラ プーリ方式によらないスローアウェイ型 $\mathrm{CBN}$ ホイー ルを開発し，アモルファステープの精密研削への応用 を試みたものである.

\section{2. スローアウェイ型 CBN ホイール}

ベルト研削は，研磨材を塗布したベルト（研削ベル ト）を用いる加工法で, 通常, 回転する硬質ゴム性の コンタクトホイールとアイドラプーリとの間に研削べ ルトを掛け, 砥石車と同様にして研削が行われる. 研 削ベルトは, 研削砥石に比べて砥粒切れ刃間隔が極め て大きいため, 切りくずポケットが大きく, 能率のよ い加工が可能である. しか子研削ベルトは工作物に対 して弾性的に接触するため, 工作物との接触面の曲率 半径が極めて大きくなる，その結果，切れ刃間隔が大 
きいにもかかわらず，個々の切れ刃の砥粒切込み深さ は逆に小さくなり，研削熱の発生が少なく，いわゆる クールカットが可能である ${ }^{3}$.

ベルト研削はこのよらな優れた研削特性を持ちなが ら，通常の砥石研削に比べて加工精度が劣るため，精 密加工法としてほとんど普及していない，その原因と しては，次のようなことが考えられる.

（1）テンションプーリによって研削ベルトに張力 を与える方式を取っているため，研削軸に上向き の力が作用し，回転精度を劣化させる。

（2）テンションプーリとコンタクトホイールの間 で研削ベルトが横振動を起こし，それがュンタク トホイールの振動を誘起する.

（3）研削ベルトの継目で剛性が変わるために，工 作物とコンタクトホイールの接触形状が変化し， 振動が発生する.

（4）コンタクトホイールの弾性変形のために, 形 状加工精度が劣化する.

一方，アモルフォステープの研削においては，砥石 目づまりと研削熱による再結晶化が最も大きな問題で ある.この点では，ベルト研削が最適である。しかも ベルト研削では，工作物の連続送りが可能である。こ れは，アモルファステープ研削の実用化のためには, 欠くことのできない必須の条件である. したがって， アモルファステープにペルト研削を適用する際の最大 の課題は, 要求される加工精度をいかにして達成する かである。

このようなことから，ベルト研削法の加工精度の改 善を検討することにした．まずべルト研削法の加工精 度が悪い最大の原因は，上述のように，テンション方 式とベルトの継目によって発生される主軸の振動にあ ると考えられる，そこで本研究では，継目のない $\mathrm{CBN}$ エンドレスベルトを採用し，テンションプーリ を用いずに外径拡張式コンタクトホイールによって, ベルトを張り上げる新しいベルト研削方式を考案し た.

試作した外径拡張式コンタクトホイールの構造を図 1 亿示す. コンタクトホイールの外周はゴムリング 6 になっている.ナット 1 を調整することによって，ス プリングコレット 4 を介してその外径を自由に調整で きる. 調整後は固定リング 7 で固定し，回転中に遠心 カでスプリングュレットが弛緩するのを防止してい る. ゴムリングは着脱が自由で, 要求に応じての適当 な硬度のものに変えることができる.ゴムリングの外 周は，あらかじめ研削盤上で通常のホイールのッルー インクと同様に，カップッルアを用いて隹正した。
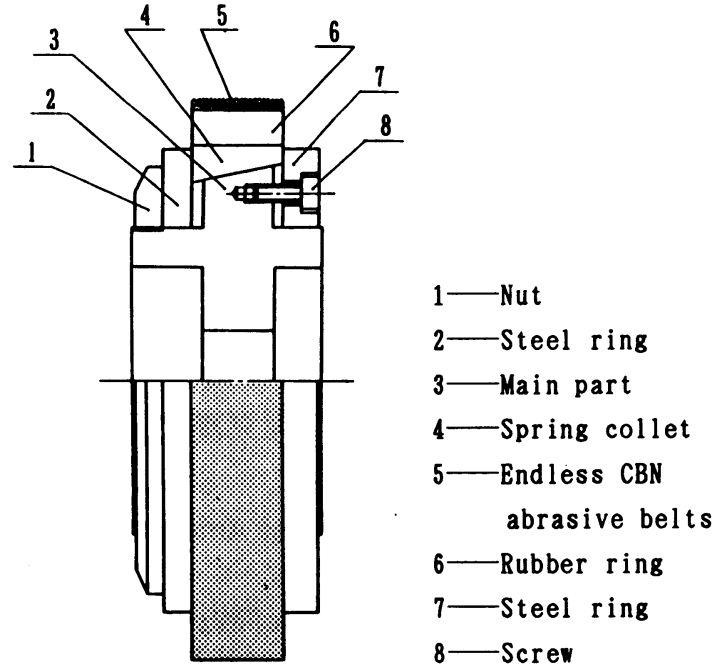

Fig. 1 Structure of throw-away CBN wheel

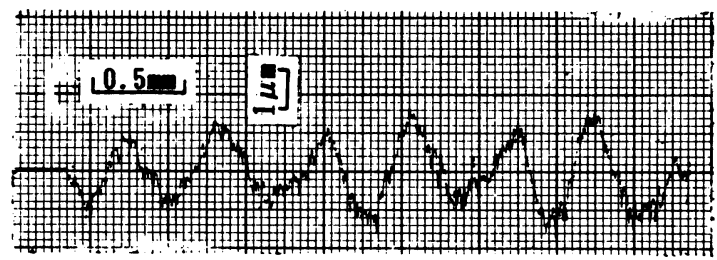

Fig. 2 Surface roughness in plunge grinding

Table 1 Grinding conditions

\begin{tabular}{l|l}
\hline Amorphous tape & $\begin{array}{l}25 \mu \mathrm{m} \times 11 \mathrm{~mm} \\
(\mathrm{Fe} \mathrm{78 \% ,} \mathrm{Si} \mathrm{13 \% ,} \mathrm{B} \mathrm{9 \% )}\end{array}$ \\
$\begin{array}{l}\text { Peripheral wheel speed } \\
18 \mathrm{~m} / \mathrm{s}\end{array}$ \\
$\begin{array}{l}\text { Tape feed speed } \\
\text { Actual depth of cut }\end{array}$ & $8 \mu \mathrm{mm} / \mathrm{min}$ \\
Endless abrasive belts & $\mathrm{CBN} \# 600$ \\
& $20 \mathrm{~mm} \times 600 \mathrm{~mm}$ \\
$\begin{array}{l}\text { Interval of intersection } \\
\text { on surface of the belts }\end{array}$ & $0.5 \mathrm{~mm}$ \\
\hline
\end{tabular}

このよ5に CBN エンドレスベルト 5 を $\mathrm{CBN}$ ホ イールと同様に使用できるので，これをスローアウェ イ型 CBN ホイールと呼ぶことにする.

\section{3. プランジ研削}

図 2 は, 粒度\# 600 のスローアウェイ型 $\mathrm{CBN}$ ホ イールを用いてプランジ研削したフモルファステープ の仕上面粗さ曲線の一例で, 研削方向に直角に測定し たものである．その研削条件を衰 1 に示す．このよう に仕上面には一定周期のらねりが形成されるが，これ は次の理由による.

本研究で使用した $\mathrm{CBN}$ エンドレスベルトは, 張力 
王・庄司・旡川・田中・茂木：スローアウェイ型 CBN ホイールによるアモルファステープの研削に関する研究（第 1 報） 1553
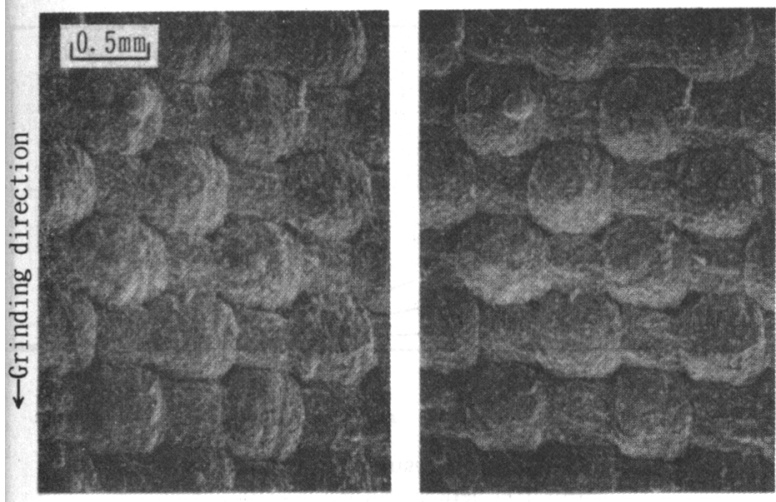

Fig. 3 SEM stereo photographs of the surface of endless CBN abrasive belts

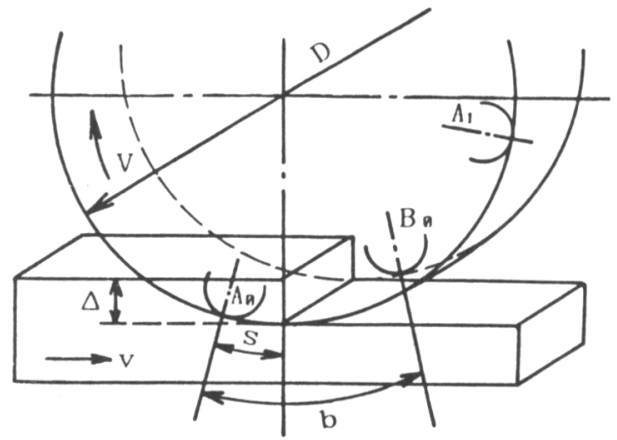

( a )

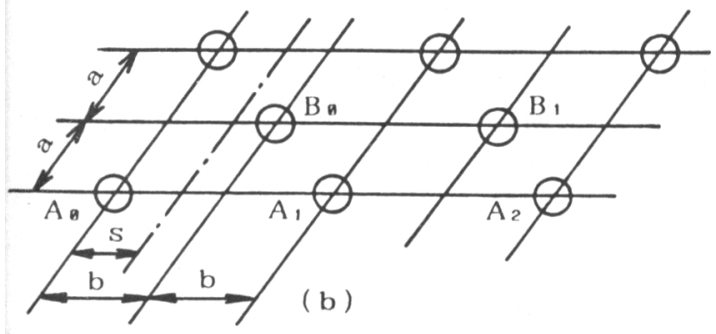

Fig. 4 Model of grinding section curve and distributing of intersection on surface of the endless CBN abrasive belts

による伸びを少なくするために，平織りの基材を使用 している. そのため, 図 3 の SEM の立体写真に示す ように, ベルトの表面には縦系と横系の交差点が, 研 削方向に整然と並んでいる. この研削ベルトはこのよ らな表面構造を持っているため, 研削液による冷却性 が優れている反面，プランジ研削を行らとこの交差点 が研削面に転写され，縦糸と同じピッチのう㸚りが形 成される.

$\mathrm{CBN}$ 砥粒の粒径は交差点に比べて十分小さいので 仕上面のらねりに対する影響は無視することができ る. そこで交差点を半径 $r$ の球と仮定し, 図 4 (b) に
示したよらに，研削ベルトの表面を縦系間隔を $a$, 横系間隔 $b$ と寸る交差点の行列と考光て, 交 差点によって作られるらねりの高さを求めること にする.

いま図4(a)のように，断面曲線を考学る工作 物断面が砥石軸の真下にきた時を基準にして，断 面曲線上に残る任意の交差点 $\mathrm{A}_{0}$ の円周距離を $s$ とする. ここで $s$ は, 反時計方向を正とし， $0 \leqq s$ $\leqq b$ である. この交差点の先端が基準断面を切る 高さ $h_{\mathrm{A}_{0}}$ は

$$
h_{\mathrm{A}_{0}}=\frac{1}{D}\left[\frac{v}{V}\right]^{2} s^{2}
$$

である.ここで， $D$ はホイールの工作物との弾 性接触面の近似直径 ${ }^{3)}, V$ はホイールの周速度, $v$ は アモルファステープの送り速度である.

このとき交差点 $A_{0}$ と相隣る縦釆列で断面曲線上に 残る交差点は $\mathrm{B}_{0}$ になり, 基準断面を切る高さ $h_{\mathrm{B}_{0}}$ は

$$
h_{\mathrm{B}_{0}}=\frac{1}{D}\left[\frac{v}{V}\right]^{2}(s-b)^{2}
$$

で与克られる. したがって交差点 $\mathrm{A}_{0}$ と交差点 $\mathrm{B}_{0}$ の 基準断面を切る高さの差は,

$$
\Delta h=\frac{1}{D}\left[\frac{v}{V}\right]^{2}\left(b^{2}-2 b s\right)
$$

になる.よって $s=0$ のとき， $\Delta h$ は最大値

$$
\Delta h_{\mathrm{m}}=\frac{1}{D}\left[\frac{v}{V}\right]^{2} b^{2}
$$

をとる.このとき図 5 に示したように，両者の作るら ねりの高さを $R_{\mathrm{P}}$ とすれば, $r \gg R_{\mathrm{P}}$ であることを考虑 して, 次式が得られる.

$$
\sqrt{2 r R_{\mathrm{P}}}+\sqrt{2 r\left(R_{\mathrm{P}}-\Delta h_{\mathrm{m}}\right)}=a
$$

式 (5)を $R_{\mathrm{P}}$ について解けば,

$$
R_{\mathrm{P}}=\frac{a^{2}}{8 r}+\frac{\Delta h_{\mathrm{m}}}{2}+\frac{\Delta h_{\mathrm{m}}^{2}}{2 a^{2}} r
$$

になる， $R_{\mathrm{P}}$ は，断面曲線に残るらねりの最大値であ る.

さらに式 (6) から, 交差点の半径は

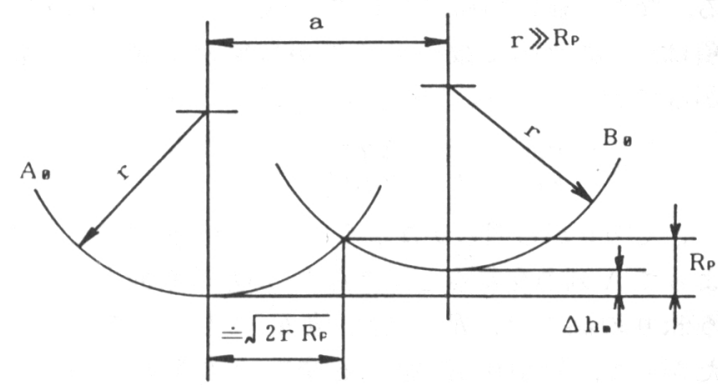

Fig. 5 Surface waviness $R_{\mathrm{P}}$ in plunge grinding 


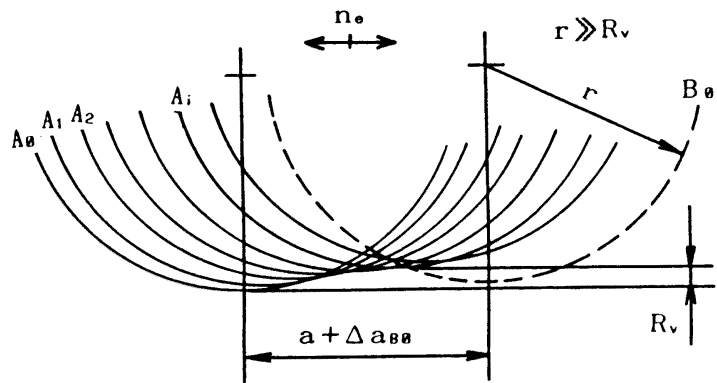

$\Delta \mathrm{a}_{\mathrm{B} \theta}=\mathrm{e} \sin \left(2 \pi \mathrm{n}_{\mathrm{e}} \mathrm{b} / \mathrm{V}\right)$

Fig. 6 Surface waviness $R_{\mathrm{v}}$ in low-frequency vibration grinding

$$
r=\frac{a^{2}}{\Delta h_{\mathrm{m}}}\left(R_{\mathrm{P}}+\sqrt{R_{\mathrm{P}}{ }^{2}-R_{\mathrm{P}} \Delta h_{\mathrm{m}}}\right)-\frac{a^{2}}{2 \Delta h_{\mathrm{m}}}
$$

である.したがって㬰際の研削仕上面のらねり $R_{\mathrm{P}}$ と ベルト表面の縦糸間隔 $a$, 横糸間隔 $b$ の測定結果か ら, 交差点半径 $r$ を推算することができる.

\section{4. 低周波振動研削}

いま，砥石軸方向に平行の低周波振動

$$
y=e \sin \left(2 \pi n_{\mathrm{e}} t\right)
$$

を工作物に付与することによって，研削仕上面に対す る交差点の影響を除去することを考える. ここで， $e$ は振幅, $n_{\mathrm{e}}$ は振動数, $t$ は時間である.

図 6 に示したように，工作物に低周波振動を付与す ることによって，先行する交差点 $\mathrm{A}_{0}$ の陰になってい た交差点 $\mathrm{A}_{1}, \mathrm{~A}_{2}, \cdots$ の切削痕が断面曲線上に残るよう になる. このとき, $\mathrm{A}$ 列の $i+1$ 番目の交差点 $\mathrm{A}_{i}$ と 交差点 $\mathrm{B}_{0}$ の作るらねりの高さ $R_{i}$ は, $s=0$ としたとき の両者の断面曲線上の高さの差

$$
\Delta h_{i}=\frac{1}{D}\left[\frac{v}{V}\right]^{2}(2 i-1)^{2} b^{2}
$$

と, 両者の $y$ 方向の間隔

$$
a_{i}=a+e \sin \left(2 \pi n_{\mathrm{e}} b / V\right)-e \sin \left(2 \pi n_{\mathrm{e}} \cdot 2 b i / V\right)
$$

を，それぞれ式（6）の $\Delta h_{\mathrm{m}}$ と $a$ に代入して求められ る.な拉，通常の研削条件では式 (10) の右辺の第 2 項は， $a$ に比べて微小であるから無視できる.した がって $R_{i}$ は, 次式で与えられる.

$$
R_{i}=\frac{a_{i}{ }^{2}}{8 r}+\frac{\Delta h_{i}}{2}+\frac{\Delta h_{i}{ }^{2}}{2 a_{i}{ }^{2}} r
$$

さて図 6 から明らかなように，低周波振動の付与に よって $\mathrm{A}$ 列の交差点と交差点 $\mathrm{B}_{0}$ が基準断面上に作る らねりの高さは， $R_{i}$ の最小値 $R_{\mathrm{v}}$ で与えられる. し たがって，最小值 $R_{\mathrm{v}}$ をる交差点の番号 $i_{\mathrm{v}}$ は, 式 (11)を $i て ゙$ 微分しゼロと置くことによって求められ

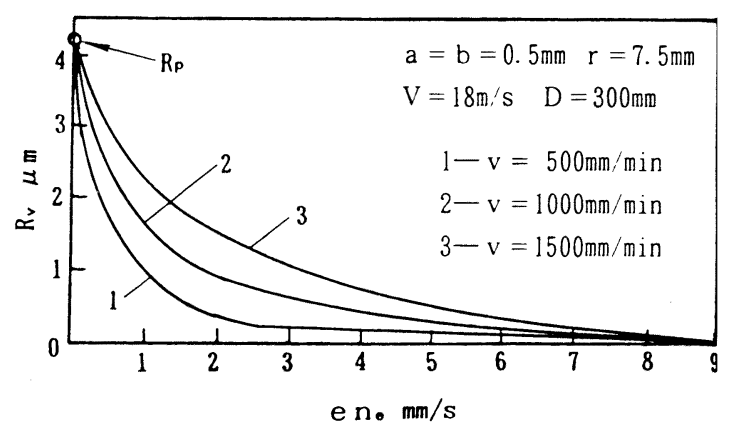

Fig. 7 Calculation results of surface waviness $R_{\mathrm{v}}$ in low-frequency vibration grinding

る. 式（11）を $i$ で微分すると，

$$
\frac{\mathrm{d} R_{i}}{\mathrm{~d} i}=\left[\frac{a_{i}}{4 r}-\frac{\Delta h_{i}{ }^{2}}{a_{i}{ }^{3}} r\right] \frac{\mathrm{d} a_{i}}{\mathrm{~d} i}+\left[\frac{1}{2}+\frac{\Delta h_{i}}{a_{i}{ }^{2}} r\right] \frac{\mathrm{d} \Delta h_{i}}{\mathrm{~d} i}
$$

である.ここで,

$$
\begin{aligned}
& \frac{\mathrm{d} a_{i}}{\mathrm{~d} i}=\frac{-4 \pi e n_{\mathrm{e}} b}{V}-\cos \left[\frac{4 \pi n_{\mathrm{e}} b}{V} i\right) \\
& \frac{\mathrm{d} \Delta h_{i}}{\mathrm{~d} i}=\frac{4}{D}\left[\frac{v}{V}\right]^{2}(2 i-1) b^{2}
\end{aligned}
$$

である. 通常の研削条件では, 式 (12) の右辺の第2 項は第 1 項に比べて熦小であり，無視できる.した がって式 (12) は, 次のようになる.

$$
\frac{\mathrm{d} R_{i}}{\mathrm{~d} i}=\left[\frac{a_{i}}{4 r}-\frac{\Delta h_{i}{ }^{2}}{a_{i}{ }^{3}} r\right] \frac{\mathrm{d} a_{i}}{\mathrm{~d} i}
$$

$\mathrm{d} R_{i} / \mathrm{d} i=0$ とすれば, 式 (15) は

$$
a_{i}=\sqrt{2 r h_{i}}
$$

になる．式（9）と（10）を式（15）に代入して解けば, $i_{\mathrm{v}}$ は,

$$
i_{\mathrm{v}}=\frac{V a / b+v \sqrt{2 r / D}}{2\left(2 \pi e n_{\mathrm{e}}+v \sqrt{2 r / D}\right)}
$$

で与えられる. 式 (17) を式 (9), (10) の $i$ に代入し, その結果をさらに(11) に代入することによって $R_{\mathrm{v}}$ が次式のと拈り求められる.

$$
R_{\mathrm{v}}=\frac{1}{D}\left[\frac{v}{V}\right]^{2} b^{2}\left[\frac{V a / b+v \sqrt{2 r / D}}{2 \pi e n_{\mathrm{e}}+v \sqrt{2 r / D}}-1\right]^{2}
$$

図 7 は，低周波振動研削に拈けるらねり $R_{\mathrm{v}}$ を上述 の式に従って計算した結果である. ここで交差点の半 径 $r=7.5 \mathrm{~mm}$ は, 図 2 の $ね$ 可值 $(4.2 \mu \mathrm{m})$ に よって, さらにそのピッチ $(0.5 \mathrm{~mm})$ から $a=b=$ $0.5 \mathrm{~mm}$ として, 式 (7) を使って求めた值である.

また図 8 は，図 2 のプランジ研削と同じ研削条件 （表 1 参照）で, $n_{\mathrm{e}}=5 \mathrm{~Hz}, e=1 \mathrm{~mm}$ の低周波振動 を付与したときの仕上面粗さ曲線の記録である．低周 波振動研削を付与することによって，ベルト基材の織 
王・庄司・㕌川・田中・茂木：スローフウェイ型 CBN ホイールによるアモルファステープの研削に関する研究（第 1 報） 1555

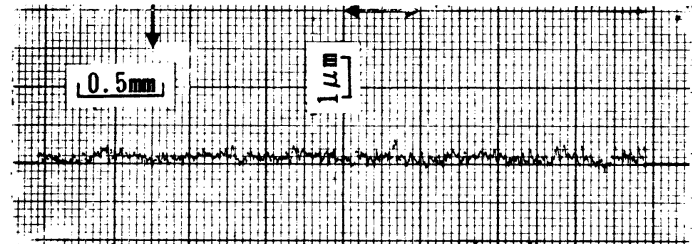

Fig. 8 Surface roughness in low-frequency vibration grinding

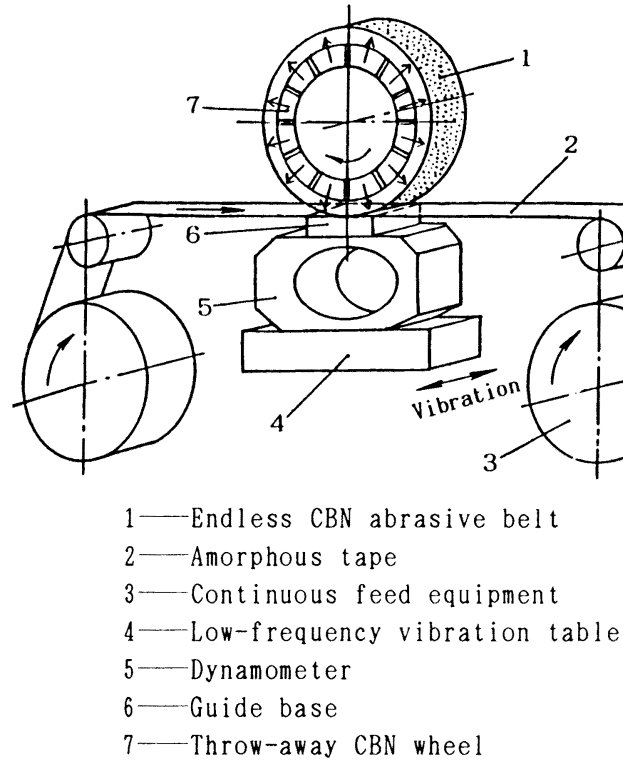

Fig. 9 Experimental apparatus for precision grinding of the amorphous tape

維交差点によるらねりが除去され，研削仕上面の粗さ が改善されることが明らかである.

\section{5. アモルファステープの連続研削装置}

图 9 は，本研究で試作したアモルファステープの連 続研削装置の概略を示す．実験時には，研削抵抗を測 定するために，低周波振動テーブルとアモルファス テープの間に弾性リング式の動力計を挿入した.

またゴム製のコンタクトホイールの弾性変形のため に, アモルファステープの両側部には約 $4 \mu \mathrm{m}$ のだれ が生じた. そこでアモルファステープの下にコンタク トホイールと同じゴム製で厚さ $5 \mathrm{~mm}$ のガイドベース を敷いたところ，だれは約 $2 \mu \mathrm{m}$ に改善された。

\section{6. アモルファステープ低周波振動研削の特性}

図 10 は低周波振動研削に打ける振動数が仕上面粗 さ $R_{\max }$ に及ぼす影響を調べた結果である. 研削仕上 面粗さは振動数 $n_{\mathrm{e}}$ の増加と共に減少し, 図 7 に示し

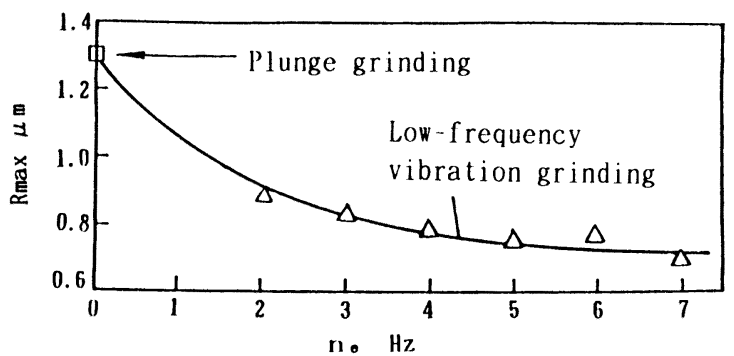

Grinding conditions: $V=12 \mathrm{~m} / \mathrm{s}, v=400 \mathrm{~mm} / \mathrm{min}, \Delta=50 \mu \mathrm{m}$ $C B N \# 600, a=b=0.2 \mathrm{~mm}$

Fig. 10 Effect of vibration frequency $n_{\mathrm{e}}$ on surface roughness $R_{\max }$

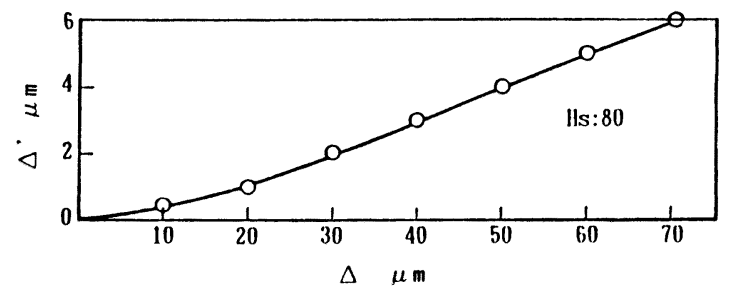

Grinding conditions: $V=12 \mathrm{~m} / \mathrm{s}, v=400 \mathrm{~mm} / \mathrm{min}, \mathrm{n}_{e}=5 \mathrm{~Hz}$ $\mathrm{CBN} \# 600, a=b=0.2 \mathrm{~mm}$

Fig. 11 Effect of setting depth of cut $\Delta$ on actual depth of cut $\Delta^{\prime}$

た理論計算と同じ傾向を示した.

図 11 は, 設定切込及量 $\Delta$ と実切込又量 $\Delta^{\prime}$ との関 係を示す.ゴムコンタクトホイールとゴムガイドベー スにはデュロメータ指数 80 のゴムを使用したが, 弾 性変形のために実切込及量 $\Delta^{\prime}$ は設定切込及量 $\Delta$ の約 1/10になった。

図 12 は, 仕上面粗さ $R_{\max }$ と研削抵抗 $F_{\mathrm{n}}, F_{\mathrm{t}}$ に対 するアモルファステープの送り速度 $v$ の影響を調べ た結果である，送り速度が増大すると，仕上面粗さ $R_{\max }$ 之研削抵抗 $F_{\mathrm{n}}, F_{\mathrm{t}}$ はやや大きくなった.

図 13 は, 仕上面粗さ $R_{\max }$ と研削抵抗 $F_{\mathrm{n}}, F_{\mathrm{t}}$ に対 するホイール周速度 $V$ の影響を調べた結果である. ホイールの周速度 $V$ が増大するに従って, 研削仕上 面の粗さ $R_{\max }$ は減少するが, 研削抵抗 $F_{\mathrm{n}}$ は増大し た. 研削抵抗の増加は, 遠心力によるゴムコンタクト ホイールの膨張のために実質切込み量が増大したから である.

\section{7. 結}

（1） CBN ホイールに比べ目詰まりし難く研削熱 の発生も少ない研削ベルトの特性を生かし, 外形 拡張式コンタクトホイールを用いたスローアウェ 


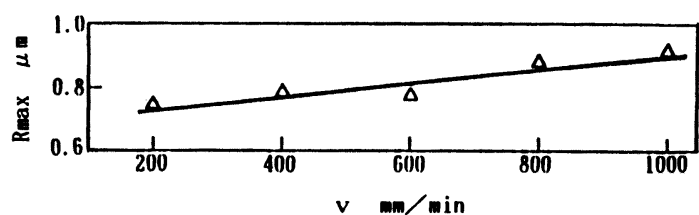

(a)

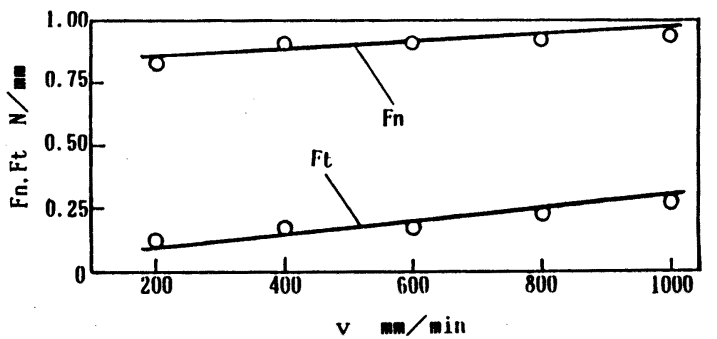

(b)

Grinding conditions: $V=12 \mathrm{~m} / \mathrm{s}, \Delta=50 \mu \mathrm{m}, \mathrm{n},=5 \mathrm{~Hz}$ $\mathrm{CBN} \# 600, a=b=0.2 \mathrm{~mm}$

Fig. 12 Effect of tape feed speed $v$ on surface roughness $R_{\max }$ and grinding forces $F_{\mathrm{n}}, F_{\mathrm{t}}$

イ型 CBN ホイールを考案した. それを用いて， アモルファステープの連続研削に成功した.

（2）平織りのエンドレスベルトを用いたため, 研 削面に縦系間隔と同一ピッチのらねりが生じた が, アモルフフステープに $5 \mathrm{~Hz}$ 程度の低周波振 動を付与することによって完全に解消することが できた.

（3） \#600のスローアウェイ型 $\mathrm{CBN}$ ホイールを用 い, 最終的に $0.8 \mu \mathrm{m} \mathrm{R}$ max 以下の粗さを達成す ることができた。

（4）テープの両側端に，ベルト研削に特有のだれ が発生したが, テープの下にコンタクトホイール と同じゴム製のガイドベースを教くことによっ て，だれは $2 \mu \mathrm{m}$ 程度に減少させることができ た.

\section{辞}

アモルフォステープは宮城県工業技術センターから 提供されたことを記して謝意を表す。

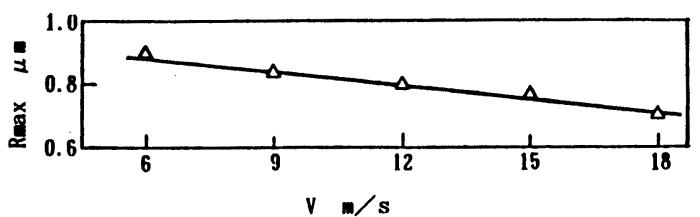

(a)

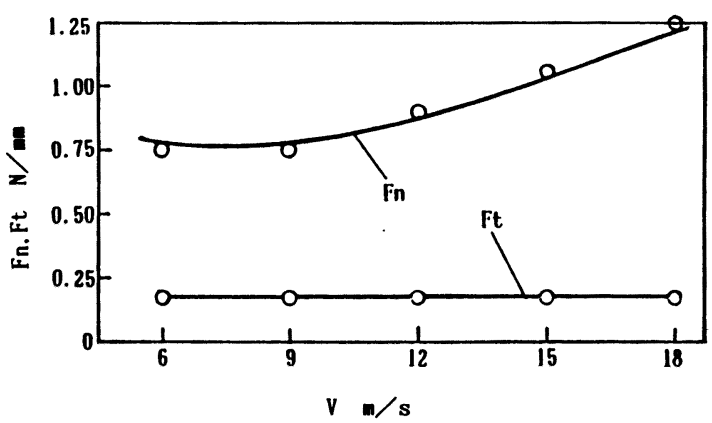

(b)

Grinding conditions: $v=400 \mathrm{~mm} / \mathrm{min}, \Delta=50 \mu \mathrm{m}, \mathrm{n}=5 \mathrm{~Hz}$ $\mathrm{CBN} \# 600, a=b=0.2 \mathrm{~mm}$

Fig. 13 Effect of peripheral wheel speed $V$ on surface roughness $R_{\max }$ and grinding forces $F_{\mathrm{n}}, F_{\mathrm{t}}$

\section{考文献}

1）增本 健：アモルファス合金一その物性と応用, アク *, (1981).

2）竹浪同人：アモルファス金属の最近の応用動向，機械設 計, 33, 1 (1989) 89.

3）松井正己, 庄司克雄：コンタクトホイールの弾性変形の 奻果一一・ルト研削に夙する研究 (第 1 報), 精密機械, 44, 2 (1978) 155.

4）杉田忠彰ほか：アモルファス金属の加工表面のキャラク タリせーション, 昭和 60 年度精機学会秋季大会学術講演 会講演論文集, (1985) 751 .

5）小林正巳：アモルファス合金の加工，機械技術，34, 3 (1986) 38.

6）馬来国漒：フモルファス薄膜，共立出版，（1988）.

7）増本 健：フモルファス金属の加工特性，機械技術, 35, 12 (1987) 20.

8）猪 浩一朗：フモルフォス合金リボンとセンサ応用, セ ソサ技術，7，1（1987）111.

9）藤森啓安：非晶質軟磁性材料，金属学会会報， 26，7 (1987) 729 . 